\title{
OPERATING URBAN PUBLIC TRANSPORT RAIL INFRASTRUCTURE AND VEHICLES OVER PLANNED LIFE CYCLE AND ITS ECONOMIC ASPECTS WITHIN THE COMPANY
}

(ANALYSIS AND FINE-TUNING OF THE SCIENCE BASED CONTINUED OPERATION PROTOCOL (SCOP) DECISION SUPPORT MODEL)

\section{Péter Takács}

PhD student

Szent István University, Enyedi György Doctoral School of Regional Sciences

E-mail: takacs.nht@gmail.com

\begin{abstract}
If you accept the principle that a tangible asset can be operated as long as it is considered usable, operating conditions must be evaluated at the end of its life expectancy. Of course, life expectancy is different when we run a light bulb or an airplane therefore we will need some risk assessment and a science based continued operation protocol (SCOP). The idea of developing a SCOP came from BKV Zrt. and it was formed by 2012, with expertise help. SCOP is a model that keeps growing and requires fine tuning but the fact that BKV Zrt applies it on a daily basis, proves its success. In my thesis I now describe the key aspects of the operation of vehicles over the planned lifespan and analyse the model for further development.
\end{abstract}

Keywords: continued operation, public transport, tangible assets, useful lifespan, investment, accounting, risks, lifespan costs,

JEL classification: $M 21, M 41, R 41$

LCC: HE305-311

\section{Introduction}

The operation of tangible assets of public transport service providers operating in some local areas of Hungary, especially the operation of infrastructure elements and vehicles, is a complex task. A significant part of the assets of the municipalities providing such services have exceeded their useful lifespan planned at the time of the acquirement. The continued operation of such vehicles is both an opportunity and a necessity for the operator. In a low budget environment, despite the fact that development and requirements for higher service quality (e.g. air conditioning, ABS, etc.) keep increasing, operating the vehicles over their life expectancy usually still seems to be the necessary-, or economic yet satisfactory solution against renovating or purchasing a new vehicle. The contradiction between life expectancy and obsolescence is that, while producing new things stimulates economic growth and creates jobs, it also generates additional costs for the society. The purchase of a new product involves the disposal of the old product, that requires storage, disposal, managing environmental and health effects. Another very important aspect of the continued operation issue is whether renovation or the acquisition of a new vehicle can have a direct benefit by reducing the operating costs. Rapid technological development and the increasing importance of innovation often result lower operating costs. Maintenance-free and energy efficient operation may well balance the increased costs caused by depreciation. The macroeconomic approach to economic benefits does not always coincide with the short- and medium-term economic interests of businesses. Territorial units of urban and suburban transport are the local area where economic and social mechanisms work adjusted to the local conditions. What makes us decide pro or con the investment when it comes to asset replacement investments, given the typically limited availability of resources and are there other 
typical factors of the given local area? During the life cycle management of devices, we aim to count with costs incurred during use, in addition to the costs of creating and establishing the device. The analysis of the operation of tangible assets, owned by companies operating in local areas, over their life expectancy should primarily focus on their direct economic analysis, and not least on their accounting context. Because this research is influenced by the laws of physics, the principles of management accounting, controlling, risk accounting and safety, the applied examination method requires an interdisciplinary approach. The thesis takes into account and evaluates the factors that are essential to fine-tune a decision-making model in this subject.

\section{Investment, continued operation and risks}

\section{Investment and maintenance}

In terms of accounting investment is the purchase, creation and production of a tangible asset, any operation for the expansion, conversion, transformation of an existing tangible asset or to increase the useful life and/or capacity of an existing tangible asset shall also be included in this category. Therefore, investment covers two types of activities as defined above: acquisition of new tangible assets and the renovation of existing ones. Renovation shall mean activities aimed to restore the original condition of a worn tangible asset, a periodically recurring operation by which the useful life of an asset is decidedly improved, its original condition and/or capacity is restored in full or almost in full, the quality of manufactured products or the use of the asset is significantly improved. Therefore, completing the renovation will increase the future benefits of the device compared to the original.

Unlike above, maintenance shall mean a routine procedure comprised of repairs and corrections so as to preserve the condition of an existing tangible asset in order to increase its useful life, including systematic preventive maintenance, major overhaul procedures performed regularly but at greater intervals, and all repair and upkeep activities which are required for the safe and reliable use of the asset and which frequently results in the repair of regular wear and tear. All we gain by maintenance is that we will be able to get the benefits the device originally carried. The meaning of maintenance, in its economic sense, is significantly different from investment as it is not considered a tangible asset but is treated as a lump-sum expense.

\section{Continued operation (prolonging life expectancy after classification without any further investment)}

When counting with any tangible asset the basic question is the life expectancy you are planning with. The planned life is intended to estimate the period that the tangible asset can be operated reliably, economically and safely. A properly planned device requires no reserves that will be wasted at the end of use, although a precise specification is a difficult task, especially when the useful life is long. An important question is which one of the high-value tangible assets with considerable operational risks can be still operated safely and economically.

When operating over the useful lifespan, you simply continue the renovation and maintenance, paying attention to their potential risks and cost-increasing effects. In many cases, the age and technical condition of the fleet and transport infrastructure, directly related to their services, of those Hungarian cities that operate public transport railway systems (Szeged, Debrecen, Miskolc and Budapest) are considered to be critical. Operation of certain devices (vehicles and infrastructure) over their intended useful life, considering safety aspects at the highest, has happened in these towns before, but current trends may increase the number of such devices, which requires a complex solution to this problem. Frequency, time and resource requirements 
of the equipment replacement typically required exceed the financial capabilities, so increasing the useful life of the existing assets seems to be a reasonable objective. Operators' rating of the vehicles that exceeded their useful lives has always been carried out at the companies completely, although typically on the basis of subjective methods at the operators' level. Regular ratings are based on available cycle order standards, technology guidelines, and manufacturer recommendations. As a result of such actions, not only did continued operation become established, but also, in several cases, assets were scrapped. The complex, objectiveand scientifically-based set of conditions for continued operation, supplementing the operators' approach, has not yet been defined. Age itself is not a professional dead end if the system in question has received the necessary technical support, often defined by guidelines, during its operation. However, if we consider technical conditions and their traffic consequences, it is clear that the current age of the corporate fleet is directly related to the technical conditions, the number of failures and their traffic consequences.

Technical conditions (BKV Zrt., 2009) and the need for reconstruction are well illustrated by the development of the number of extraordinary events that significantly affect passenger volume (Figure 1).

\section{Extraordinary events on Metro line M3}

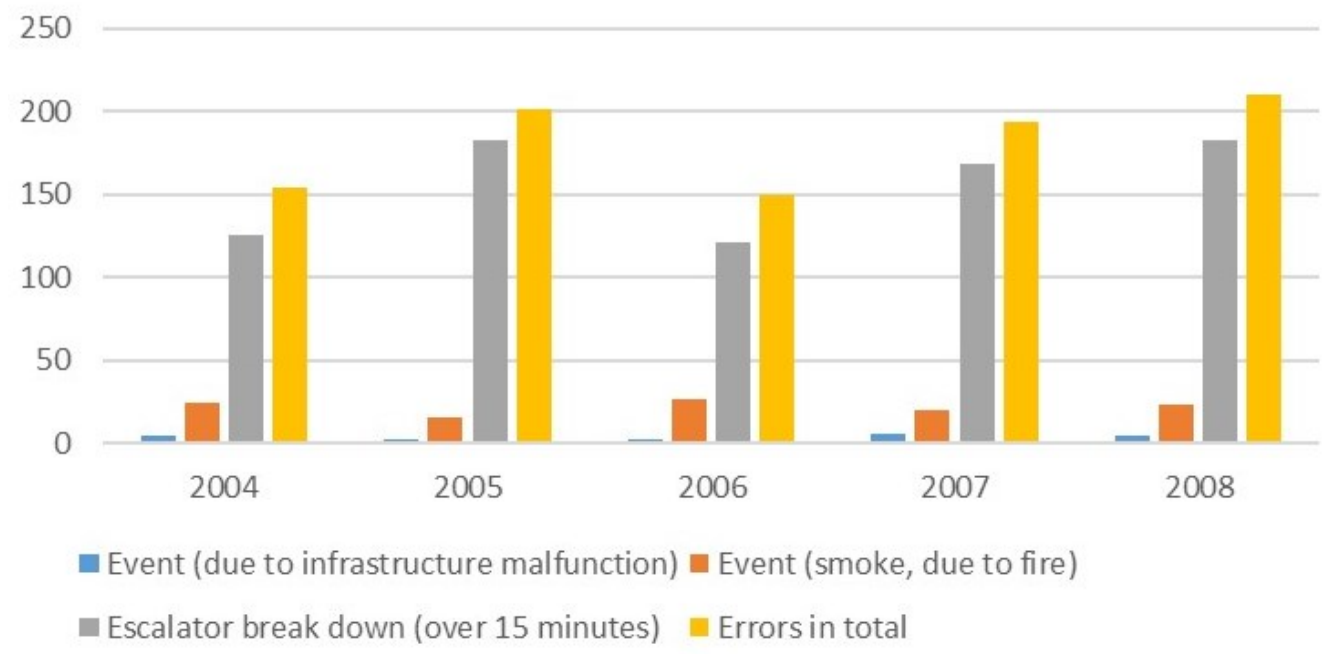

Figure 1 Extraordinary events on Metro line M3

Source BKV Zrt.,2009.

In addition, the operation of the fleet over its useful lifespan raises the question of the degree of risk that the operator can take or has taken. In view of all these factors and processes, as well as the related risks, the management and experts of the Budapest Transport Private Limited Company (BKV Zrt.) raised demand for developing a system that supports continued operation of assets over their useful life and infrastructure not only from the operators' aspect but on a scientific, audited basis. In 2012, the management of BKV Zrt. made a professional decision on developing a scientifically based system to fill this gap. The so-called Science based Continued Operation Protocol (SCOP) model has been developed for the development of the methodology and technology to increase the useful lifespan on a scientific basis. The new model defines the conditions set for continued operation by integrating technical, safety and economic aspects into a complex system, based on an objective evaluation methodology, thus reducing the level of operators' risk and responsibility to a level that is acceptable for the Company's management. 


\section{Risks}

Risk, in simple terms, involves the chance of hazard or great loss created by some action. Many areas of life carry risks, including risks that root in in failure to act. When dealing with risks, we look for the likelihood of the hazard or loss occurring and the effect it would have if it occurred. Risk management's planning, organization, management, control, and development functions are designed to prevent or minimize such unexpected events. Responsibility and risk management are layered at different levels of society. At an individual level, there is a wide range of things, related to a particular task, as it can have very different effects and consequences in different areas of life. Responsible corporate management requires the implementation of comprehensive risk management that, embedded in each business process, helps the management reach its goals in a coherent way, risks that hinder or delay growing profitability and the methods invented to manage those. It should inspire employees to forecast risks and their effects in advance so that preventive protective decisions can be made and measurements can be taken. Employees need to adopt the existing risk management practices and they should be encouraged to participate in risk management.

Goals:

- to introduce a coherent risk management approach applying the equal principles of analysis, evaluation and prioritization;

- to develop and maintain corporate governance and a decision support structure;

- early identification, management and monitoring of risks;

- conscious management and supervision of operational and organizational risks;

- to establish an annual internal audit work plan based on risk analysis.

It is important that the goals are known at all levels of the company and that the concerned employees need to identify with them, as this provides the opportunity to recognize relevant risks, to make their quantitative and qualitative measurement, and to take the necessary action.

There is a slightly different approach to managing macroeconomic risks. There may also be risk factors during the operation of a company that are implicit and cause losses to another group, area or region indirectly. The transport sector involves that such issues will arise, since when it is missing directly affects, for example, the performance of the economy. The greater the importance of a given transport element in the daily motion, the greater its impact in the event of a hazard. So it really matters how you assess this type of risk in each region and how much effort you do to avoid it.

\section{Science based Continued Operation Protocol (SCOP) model}

\section{The grounds of SCOP}

The average age of the BKV's asset fleet is beyond the planned lifespan, so the matter was worth making a comprehensive analysis. The operator responsibility was often close to, or, in many cases, exceeded the level of the risks to be taken, there were practically no external requirements for the useful (expected) lifespan of the assets. The operational period of the asset fleet could be determined on the basis of corporate considerations (primarily technical and operational safety), and only previous practice was available to the decision-support (team) and decision-maker to determine their operating period. The manufacturer's recommendations did not constitute unconditionally acceptable directives to exceeding the normal operating limit, the technical licensing and examination procedures did not fully cover the device, thus their findings were never considered relevant to the examined matter. Naturally and intentionally, 
not every single component of a device is examined during the use of a device (those are matters of planning), but the operating conditions are influenced by the laws of physics regardless of what the operator does, thus a well-defined expansion of the operation limits and the applicable terms should only be executed on the basis of the respective findings of the knowledge base beyond the ordinary areas of operation (Vermes, 1997). This will create a quality assurance of technical and operational safety issues and complete the professionally supported operator liability.

\section{SCOP principles}

During the development of the SCOP it was high priority that BKV Zrt. should develop a complex and science-based methodology, and a related model that is user-friendly and supports the operative work efficiently, and supports the decision maker when it comes to continued operation by providing an objective assessment. (Fiáth et al., 2016). The Company has formulated a requirement from the SCOP to be fully compliant with the applicable Public Service Contract and with the relevant requirements of accounting, investment preparation and applicable standards / technologies.

\section{The principle of providing scientific bases}

During the development of the SCOP, only assets / systems that were over their planned useful life by the Company's accounting policies were analysed and investigated.

SCOP is interpreted and developed for those component / components only that are decisive for the lifespan of the device / system and are not part of the maintenance and repair technology.

Therefore the accomplished SCOP did not cover the following matters:

- revealing and assessing technical conditions,

- assessment on the adequacy of the cycle order standard,

- assessment on the inspection, maintenance and reparation regulations, and compliance check,

- assessment on the theoretical structure and future concept of the current assets / system,

- counting with the degree of obsolescence of the asset system.

Besides the above, in the course of developing the technology that increases useful lifespan, operational experiences (Fiáth et al, 2016) have been widely considered and deemed to be crucial.

\section{Theoretical structure of the SCOP model}

SCOP is a special review list of tasks that determines, on the basis of a detailed measurement protocol, what technical measures need to be performed on a given device / system, their technical content, sequence, and once the interventions are applied, the specific value for increasing its service lifespan (Figure 2). In addition, the developed system ensures the assessment and classification of the exact results of a specific set of tasks (technical module). 


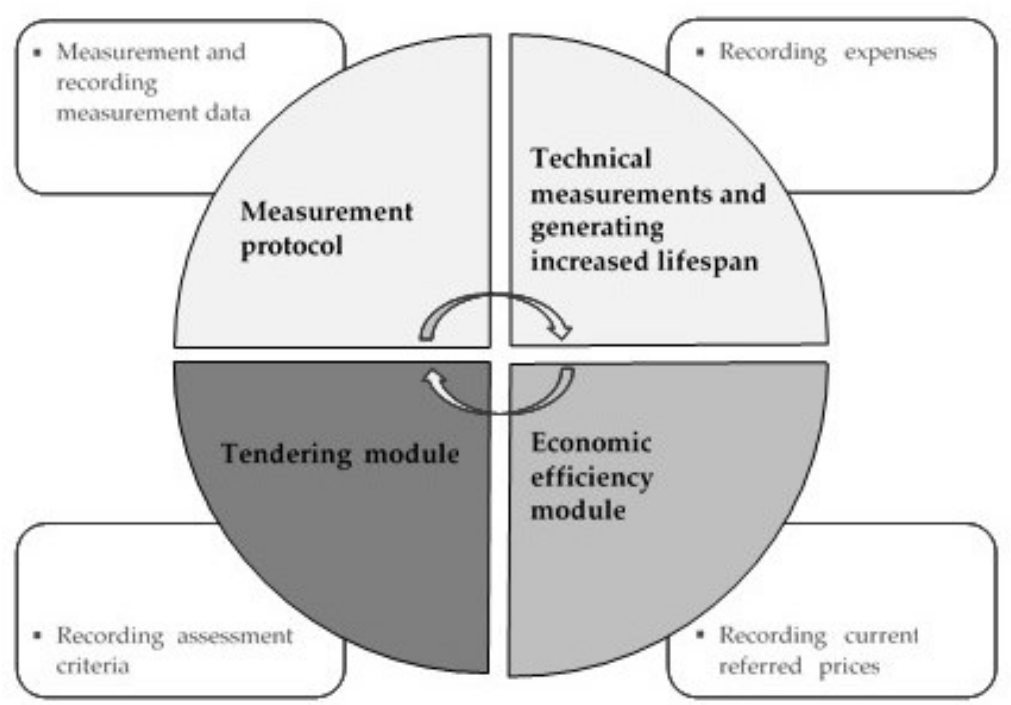

Figure 2: Theoretical structure of the SCOP model

\section{Source Fiáth et al, 2016.}

The complex model also covers the economics analysis, performed before the implementation, of the specified technical measurements, taking into account the generated increase in the useful life (economic efficiency module), as well as the tender qualification system applicable for the related asset procurements (tendering module).

The primary purpose of the Science-Based Continuous Operation Protocol methodology is to determine whether or not a given asset / equipment can be continuously operated on a vehicletechnical, safety, or economic basis. The procedure complemented by SCOP provides an opportunity to consider investment alternatives in your decisions (Table 1).

Table 1 Investment options

\begin{tabular}{|c|c|c|c|c|}
\hline \multicolumn{5}{|c|}{ INVESTMENT OTIONS } \\
\hline \multirow{5}{*}{$\begin{array}{l}\text { RELATED } \\
\text { COSTS }\end{array}$} & $\begin{array}{l}\text { Technology to } \\
\text { invrase useful } \\
\text { lifespan }\end{array}$ & $\begin{array}{l}\text { Main renovation to } \\
\text { increase lifespan }\end{array}$ & $\begin{array}{l}\text { Procurement of used } \\
\text { assets }\end{array}$ & $\begin{array}{l}\text { Acquirement of new } \\
\text { assets }\end{array}$ \\
\hline & $\begin{array}{l}\text { Costs related to } \\
\text { increasing useful } \\
\text { lifespan } \\
\text { - Costs of reparation } \\
\text { work related to } \\
\text { useful lifespan } \\
\text { - Depreciation } \\
\text { - Residual value }\end{array}$ & $\begin{array}{l}\text { Costs related to the } \\
\text { main renovation } \\
\text { - Costs of the main } \\
\text { renovation } \\
\text { - Depreciation } \\
\text { - Residual value }\end{array}$ & $\begin{array}{l}\text { Costs related to the } \\
\text { acquirement of used } \\
\text { assets } \\
\text { - Acquirement costs } \\
\text { - Depreciation } \\
\text { - Costs related to the } \\
\text { cycle system } \\
\text { - Costs of ancillary } \\
\text { - infrasrtucture }\end{array}$ & $\begin{array}{l}\cdot \text { Acquirement costs } \\
\text { - Depreciation } \\
\text { - Costs of ancillary } \\
\text { - infrasrtucture* }\end{array}$ \\
\hline & $\begin{array}{l}\text { Cost related to the } \\
\text { cycle system }\end{array}$ & $\begin{array}{l}\text { Cost related to the } \\
\text { cycle system }\end{array}$ & $\begin{array}{l}\text { Costs related to increasing } \\
\text { useful lifespan } \\
\text { - Costs of reparation } \\
\text { work related to useful } \\
\text { lifespan } \\
\text { - Depreciation } \\
\text { - Residual value }\end{array}$ & $\begin{array}{l}\text { Cost related to the } \\
\text { cycle system }\end{array}$ \\
\hline & Residual value* & Residual value* & Residual value* & Residual value * \\
\hline & $\begin{array}{l}\text { Costs related to the } \\
\text { acquirement of new } \\
\text { assets }\end{array}$ & $\begin{array}{l}\text { Costs related to the } \\
\text { acquirement of new } \\
\text { assets }\end{array}$ & & \\
\hline
\end{tabular}

Source Fiáth et al, 2016. 


\section{SCOP analysis and observations}

The developed model defines the conditions set for continued operation by integrating technical, safety and economic aspects into a complex system, based on an objective evaluation methodology, thus reducing the level of operators' risk and responsibility to a level that is acceptable for the Company's management.

\section{Technical module}

The module defines the technical framework and conditions for operation over the useful lifespan and proposes the recommended period for the safe continued operation. The fields of the study while developing the module are:

- applicable regulations,

- operating limit (factory recommendations, operating experience).

The exact results of the measurements are evaluated and classified. The tests gave complex results for both rail vehicles and infrastructure. In many cases, the results of the measurements were favourable, so the decision on the safe continued operation could be made for these devices without additional intervention. In many cases, knowing the results of the measurements, it became necessary to apply a certain level of technical intervention, after which it became possible for the operators to make supported decision on the safe continued operation on objective grounds. Since the start of the application, no SCOP test has been run that would have required the vehicle to be removed from operation or scrapped, in case of neither the railway vehicles nor the infrastructure elements.

\section{Economic efficiency module}

The purpose of the module is to examine whether the technical interventions defined in the technical module can be carried out economically or not, and to evaluate different investment alternatives for return on investment (use of a useful life-increasing technology, life-long renovation, purchase of used equipment, purchase of new equipment) applying complex costeffectiveness calculations. The assessment interval changes with the expected useful lifespan of the tested asset; the model calculates that the maximum useful life of an asset is max. twice as much as defined in the accounting policy, after which a new device is required. The method also includes the possibility to evaluate subjectively (service level).

\section{Tender module}

The purpose of the module is to ensure that bids received by the Company for its own tenders are judged uniformly. An adjustable model has been developed that counts with cost-type and non-cost-type elements of the tenders and the result is based on these.

\section{SCOP strengths}

SCOP is a complex science-based methodology that takes experiential knowledge into account. It is unique, as currently no other Hungarian tram operating company uses such a model or even a similar one. Its modules are linked to each other and fit together, but the technical module can perform its decision support function even on its own. It is user-friendly, its application is a series of logically based steps. Operating areas perform measurements for vehicles in a manner that is adapted to the maintenance cycles. By applying SCOP, you can increase the quality indicators of your operations and at the same time detect the amount of additional costs 
necessary for the continued operation, but originating in the failure of renewing the assets. It facilitates meeting the company's obligations under the Public Service Contract (quality indicators, operation and maintenance of vehicles and infrastructure, renewal of assets). In the SAP PM module, objects to be used for SCOP accounting have been developed to ensure a consistent and clear expense report. After fine-tuning, the application of the SCOP methodology can be extended to other sectors. Applicability of the measuring tram in the SCOP can support infrastructure investment decisions.

\section{SCOP weaknesses}

It does not count with the useful life costs of assets, so it needs to be developed with a life cycle management approach. It is necessary to track in the Company's accounting policies the financial effects of extending the useful life. As no significant intervention has been made based on the measurement results so far, opportunities offered by the economic efficiency and tender modules have not been fully exploited in practice. Initially, users of special fields were averse from applying SCOP.

\section{SCOP fine tuning aspects}

Of course, the fine-tuning aspects are rooted in the weaknesses of the model, the two main elements of which are ignoring lifespan costs and proper handling in the accounting.

\section{Life cycle management}

It was originally interpreted as referring to a product that refers to the period from the beginning of manufacturing the product or product group or their appearance on the market until the end of the manufacturing or withdrawal from the market. It was later extended to technologies, and even organizations, first and foremost to enterprises, in the context of corporate strategic activities, investments and changes in the mission and long-term goals of companies. Recently, environmental and efficiency considerations have been emphasised when applying life cycle approach. As a result, a new methodological development has complemented the calculation of life cycle costs. This new line is the life cycle analysis (Tóthné Szita, 2008), that includes an overview of the effects of the given investment on the environment and its environmental elements (Figure 3).

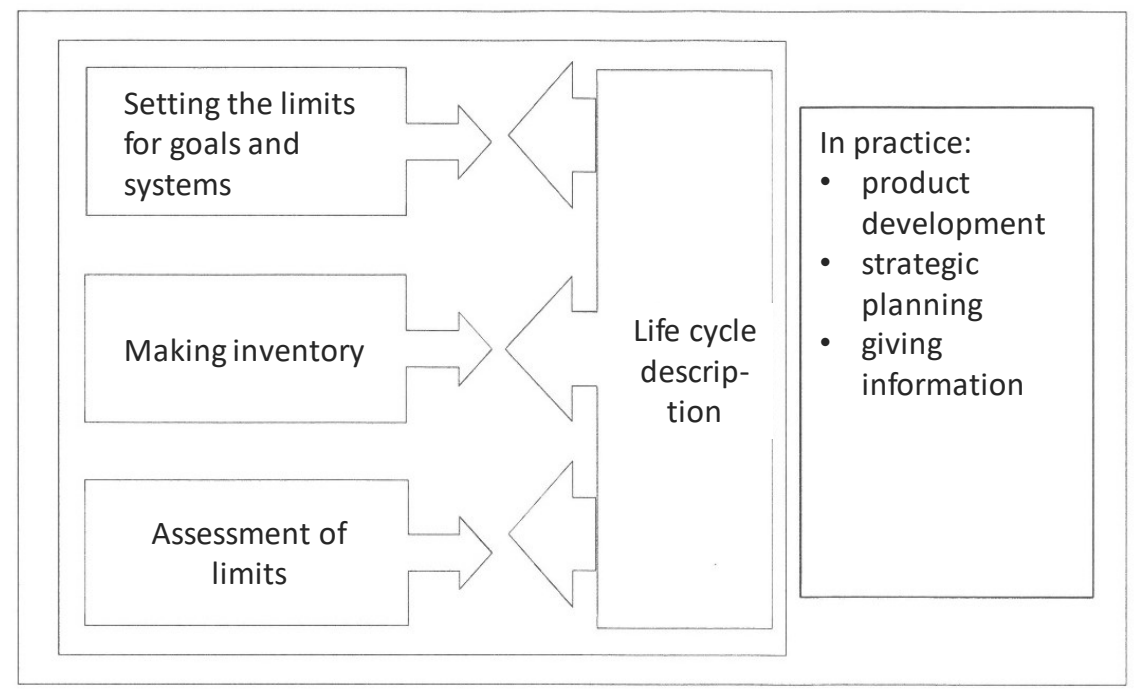

Figure 3 Stages of the life cycle analysis

Source Tóthné Szita K., 2008. 
Conditions of the effective operation:

- activities carried out in accordance with the original technological standards to be fully implemented,

- unexpected failures resulting from the operation to be repaired and fixed in time and adequate quality.

The optimal use of the available resources, both technically and economically, can be achieved by modernizing the monitoring and maintenance system, that might include expanding the maintenance system with proactive life cycle management. In the context of maintenance of technical asset systems, life cycle management is a system designed to optimize the so-called life cycle cost over the entire operating life of an operating asset system without significantly reducing its performance. Applying it, technically and economically optimal operation can be realized during the lifespan of the affected device or device system. Advantages of the method are objectivity and predictability.

The development of a maintenance strategy based on a life cycle cost analysis requires large amounts of available data, collected over the years in an appropriate structure. In addition, it is necessary to make calculations for the future useful life of the product based on a good engineering assessment.

In the context of continued operation, it is not enough to make a decision based on the evaluation of one-time investment costs only, but it is also necessary to count with all costs emerging during the operation. When examining investment alternatives, you act with due diligence when during the establishment or renovation you also analyse the cash flows for the full lifespan.

\section{Business economics and accounting}

\section{The principle of matching (content principles)}

The expenses of investing activities appear in the list of costs of the business over time because they are invested assets and serve the business in the long run, for at least one year. As a result, the earnings will be reduced over several years by depreciation. The accounting principle of "matching" applies because the "acquired" and "renovated" assets bring lasting economic benefits and, with the amortization distributed over the period of generating profit, revenues and expenses are recognized in the same period, thus the perception of business performance stays intact. The corporate tax base is balanced, unlike as if it was for maintenance. From a macroeconomic point of view, the state budget receives its revenue at the "due" time, while in the case of maintenance, the corporate tax base of the current year is reduced by the amount debited from the earnings of the year when it occurred. In the case of maintenance, the tax is returned to the budget from the generated profit only by deferring it to subsequent years. The Accounting Act only provides a framework for accounting in the case of investment, renovation and maintenance. The business needs to do the actual rating with regards to all circumstances. Each activity should be judged on its content regardless of its value!

\section{Depreciation charge}

The value of tangible and intangible assets forming part of the assets of a business gradually decreases as a result of physical deterioration and technical obsolescence, and its value is transferred into the value of new products or services in the form of depreciation expense. The value transfer process goes through the depreciation, so determining its extent is not a financial 
issue but a budget administration one! The depreciation charge recognized as a cost must be recovered by the market price, since it provides a return on the investment. The amount of annual depreciation shall be planned in the light of the expected useful lifespan of the asset and shall be recorded each year from the date on which the asset is capitalised (commissioned), whether the business is profitable or lossmaking for that year. In addition to the technical approach and the factory recommendations, the economic approach is also important when determining the useful life! The useful life in accounting does not necessarily have to coincide with the technically determined expected useful life, as it may be affected by the nature of the company's operations. From the management point of view the definition of the so-called "residual value" is essential, which should reflect the expected market value of the asset at the end of its useful life. This is important because the residual value will be recorded in the accounting records at the end of the estimated useful life.

\section{Impact on the financial management at the end of the useful life}

The asset is completely worn out and will be scrapped. During scrapping, there may be reusable items that are stocked and cannot be used. The device will be removed from the books. From an economic point of view, it is ideal that the sum of the materials, components and the proceeds from the disposal of inventories reaches or exceeds the book value, which is the same as the residual value. Otherwise the company will have deficit.

The device is still in a usable state, but the company does not need it anymore. The device must be sold at least at its book value, which results in derecognition from the books. Book value deteriorates, income improves the profit.

The company still wants to use the device because it cannot get or it is not worth to get a new one (continued operation). The book value of the asset equals the residual value. If there is no intervention, it will remain in the books but no further depreciation will be recognized. It is possible to reduce the residual value to a lower value without incurring additional expense and to recognize the difference as a depreciation charge over a new defined useful life, but this is not very effective at typically low residual values.

\section{Useful lifespan and residual value}

Depreciation is a major part (15-30\%) of the expenses of transport companies, so determining the useful life and the optimal value of the residual value is high priority. Increasing the useful life and, consequently, establishing a low residual value from an economic point of view may result in the need for replacement of the asset before the return on the investment or the invested capital shall not be returned by the time that new vehicles come to the market and that leads to deficit. If the useful lifespan of an asset is unduly shortened can also be a problem, as high depreciation can cause losses by significantly increasing the self-expense of the product or service. In the case of a realistic, higher residual value with a shorter useful life, this problem can be eliminated.

\section{Link between the depreciation charge and corporate tax}

The rate of depreciation is stipulated in the Act on corporate tax, which aims to prevent businesses from avoiding their corporate tax liability through depreciation. If your business accounts a higher depreciation charge than the statutory rate, you need to increase your corporate tax base by the difference, so even a loss-making company may pay corporate tax. 
Conversely, if a business accounts less depreciation than the statutory rate, it may reduce its corporate tax base by the difference, so even a profitable business may not pay corporate tax.

\section{Book value (net value)}

The book value of assets after all is determined as follows:

- the cost of the asset,

- its useful lifespan in months,

- residual value, that is the market value expected at the end of the useful life,

- calculation of the depreciation, that can be: Linear (typical), Degressive (expedited), Progressive (delayed) or Proportionate to performance.

\section{Correspondence between the market value and the book value (net value) of the assets}

Assets are to be valued at the end of the year and if the business considers that its carrying amount is significantly / permanently below / above market value, the accounting records should be adjusted to the market value. If market value is lower than the book value, extraordinary accelerated depreciation should be recognized as other expense, which results in a loss of profit and an increase in the corporate tax base. If market value is higher than the book value, the difference between the market value and the book value is recognized as a value adjustment as part of the book value of the assets. This way it is guaranteed that the market value is listed in the assets column of the balance sheet. You should also show this positive difference on the Liabilities side among the Equity items in the Valuation reserve.

\section{Revaluation}

Companies should have the revaluation amount audited with an independent auditor. As a result of revaluation, the book value of the assets in the balance sheet will increase (value adjustment) and the amount of equity, including the valuation reserve, will increase the same. It has no influence on the earnings. It has no effect on further depreciation or useful life of the asset and no depreciation is recognized after the valuation reserve. This difference remains intact in the books until the market value of the asset is reduced or increased or when the asset is delisted. If the market value changes, the balance sheet should be adjusted in the same way as before. This equity item, together with the value of the asset, is derecognised permanently once the asset is also derecognised (e.g. scrapping or sale). Revaluation increases the value of the company's assets and equity.

\section{Operation over planned lifespan and life cycle analysis in the world}

In numerous countries of the world, we can find examples for operating vehicles over their useful lifespan in cities. Decision makers decide on further operating the vehicles, or operating them after refurbishment due to cost-effectiveness, and against purchasing new vehicles. Further operation without refurbishment is possible if the technical condition of the vehicle and its life-cycle costs make it possible. More often, the solution is to operate the vehicle after refurbishment. More companies use this solution than we would think. It is practical to make this decision after careful consideration of technical and economic aspects. There are examples of practice all over the world to operate refurbished, modernized, upgraded vehicles, which are capable to meet the technical and safety requirements of our era. The high age of a modernized vehicle in itself is not a professional dead end if the given system receives the necessary repairs, maintenance and modernization during its operational lifespan. There are several examples when the original manufacturer himself carries out the refurbishment of railway vehicles. 
Recently, there were such refurbishments in Prague, Helsinki and in the USA (IHO.hu, 2020). In Washington in 2006 metro carriages supplied by Breda in the 1980s with fleet numbers 20002075 were up-graded in a way that their useful life lengthened by further 20 years. In the frame of the refurbishment the carriages were renovated, they received new propulsion, new driver's $\mathrm{cab}$, vehicle control device, door control system and brake system, and air-conditioning. Due to the intervention, energy consumption and maintenance requirement of the cars were reduced, while their reliability, availability and operational safety improved (wmta.com, 2006). In 2019, Trimet, the greatest transit service provider of Oregon, USA, began the renovation of his vehicles SD660 Type2 and 3, manufactured in 1984-86, the refurbishment is expected to be finished in 2025 (railwaypro.com, 2019). PKP Intercity, the subsidiary of PKP Group, the Polish national railway company, which provides long distance passenger train services, declared last year that they are continuing their great scale modernization program started in 2012. In the framework of this, besides purchasing new rail cars an electric regional motorcars, they are modernizing a significant part of the existing rolling stock, too (railtech.com, 2019/a). In Helsinki - just like in Budapest $\neg$, a decision was made to refurbish the metro trains, and the renovation of $39 \mathrm{M} 100$ and 12 M200 vehicles began in 2019. These vehicles manufactured between 1977 and 1984 will be reconstructed to full extent, from the car-body to the passenger compartment (railtech.com, 2019/b). In Prague, the renovation of the Russian metro vehicles type 81-717/714 started in 1996 and ended in 2011, and the useful life of the trains was lengthened by 15 years (railwaygazette.com, 2011).

Expediency of lengthened operation can be greatly confirmed by the low rate of the operational costs, which is to be considered for the whole lifespan. In numerous countries in the world lifecycle cost management is applied in certain industrial sectors, and development of the research methodology, as well as assessment of the data is continuous. In Western and Northern parts of Europe the method was used already in the 1990s, although Central and Eastern Europe still falls far from this. On the basis of the present experiences, we can state that this technique has traditions in the United States. Since 1991, FHWA (Federal Highway Administration, USA) has been playing an outstanding role in spreading the use of lifecycle cost in the United States. Besides the USA, this method is widely used in Canada, Japan and Australia (Tóthné Szita, 2008).

\section{Summary}

There is a coevolutive link between transport and urban development. They can support and prevent each other's development at the same time, so their relationship has high priority. Territorial units of the city, area and region can be placed in a location of transport that leads to balanced growth. In complex relationships between large systems, it is often the case that seemingly insignificant factors can result in significant changes (Káposzta, 2016). The assets and operating costs of urban railway companies are significant. As the approach of investment co-operation between business associations and municipalities does not rest on the same grounds, the emphasis may shift. Different things are valuable for each party, which may eventually lead to half-way solutions. The utilization and efficiency of fixed rail transport varies from region to region. There are basically two types of replacement investments, either renovating or replacing vehicles that have reached the end of their planned lifespan. The continued operation of an old vehicle without a renovation seems to be a secondary solution, but it would have been a premature statement without analysis. If you accept the principle that a tangible asset can be operated as long as it is considered appropriate, you also need to look at the way its condition should be evaluated at the end of its technical lifespan. Of course, it does matter whether it is a lightbulb or an airplane you are trying to continued operating, so we need risk assessment and a science based continued operation protocol. If you come to the conclusion 
that there are no technical limitations to the continued operation, risk is low, and cost-effective with regard to one-time payments, you need to consider what else to contemplate when evaluating the long-term financial management of the company. Accounting basically implies two options, to replace or to renovate the tangible asset, but in practice it is different, namely, that there may be added a continued operation period before the investment. In the first round, BKV Zrt. examined on the technical feasibility of continued operation focusing on the risks and evaluated the options on the basis of one-time costs. The SCOP model has been developed, that proved to be well applicable, but its fine-tuning should also include an assessment of the financial impact on the Company's long-term operation. In my analysis, I highlight the importance of developing life cycle management and corporate accounting policies that can help you find the optimal solution. Regional analysis is also a precondition for developing a complex methodology applicable at the national economy level (Tóth, 2016). As the cities operating urban railway companies are located in different regions (Debrecen, Miskolc, Szeged, Budapest), it is advisable to conduct a territorial survey to explore the specific features of the area. The purpose of territorial structure studies is to find out the common features the area and how they change. For Budapest and the rural cities operating the Hungarian urban railway companies, it may be sufficient to analyse the economic, social and settlement network indicators of the respective territorial unit, supplemented with data on the specific subject of the given company. At first sight it can be said that there is a gap between Budapest and the big cities in terms of development and economic potential, but Debrecen, Szeged and Miskolc can be better examined in terms of differentiation. In order to provide an adequate answer to the question of continued operation in the future, a regional analysis will also be required.

\section{References}

1. Bata I. (2000): A Budapesti metróközlekedés három évtizede, BKV Rt.

2. BKV Zrt. Müszaki Igazgatóság: Vezetői tájékoztató (2009)

3. Csomós Gy.(2011): A közép-európai régió nagyvárosainak gazdaságirányító szerepe, Tér és Társadalom, Vol.25 No.3., 129-140.p., ISSN0237-7683

4. Egri Z. (2014): A város- és várostérség tipizálás alapjai Kelet-Közép Európában, Tér és Társadalom, Vol.28 No.2., 87-104.p., ISSN0237-7683

5. Fiáth A.-Nagy V.-Takács P.-Balogh L.-Bálint Á.-Nagy B.-Dinya M.(2016): A közlekedési eszközpark és infrastruktúra hasznos élettartamát tudományos alapon növelő technológia kidolgozása a BKV Zrt. számára, Vezetéstudomány, Vol.47. No.3, 2-11.p., ISSN0133-0179

6. iho.hu (2020): Újat vagy felújítottat?, Forrás: http://iho.hu/hir/ujat-vagy-felujitottat200304 ,Letöltve: 2020.04.24. 08:30

7. Káposzta J. (2016): A területi különbségek jelentősége a komplex több dimenziós mérések rendszerében, Nemzeti Közszolgálati Egyetem prezentáció

8. railtech.com (2019/a): PKP Intercity invests in dining cars, Forrás: https://www.railtech.com/rolling-stock/2019/02/18/pkp-intercity-invests-in-diningcars/?gdpr=accept , Letöltve: 2020.04.23. 11:00

9. railtech.com (2019/b): VR Group to retrofit 51 trains for Helsinki Mtero, Forrás: https://www.railtech.com/rolling-stock/2019/04/30/vr-group-to-retrofit-51-trains-forhelsinki-metro/ , Letöltve: 2020.04.23. 11:20

10. railwaygazette.com (2011): Praha metro car modernisation complete, Forrás: https://www.railwaygazette.com/praha-metro-car-modernisationcomplete/35856.article, Letöltve: 2020.04.24. 11:30)

11. railwaypro.com (2019): Siemens Mobility to overhaul Portland TriMet's LRVs, Forrás: https://www.railwaypro.com/wp/siemens-mobility-to-overhaul-portland-trimets-lrvs/ , Letöltve: 2020.04.23. 10:00 
12. Rechnitzer J.(2016): Elmozdulások és törésvonalak Kelet-Közép-Európa térszerkezetében, Tér és Társadalom, Vol.30 No.4, 36-53.p., ISSN0237-7683

13. Section 3 (4) of Act $C$ of 2000 on Accounting

14. Tóthné Szita K.(2008): Életciklus-elemzés, életciklus hatásértékelés, Miskolci Egyetem, 15-47.p.

15. Tóth T.(2009): Területfejlesztés, Gödöllő SZIE GTK

16. Tóth T.(2016): Regionális gazdaságfejlesztési és ágazati menedzsment, In: Szügyi, György; Ritter, Krisztián; Bakos, Izabella Mária; Gerencsér, Ilona (szerk.) Magyarország: Szent István Egyetemi Kiadó, (2016) pp. 102-133. , 32 p. Gödöllö

17. Vermes, P. (1997): A vevőszolgálat, a fenntartás, valamint a hiba- és gyengepontelemzés complex kölcsönhatásai, PhD-dolgozat. Gödöllö: Szent István Egyetem

18. WMTA (2006): Semi-Annual Status Report on Railcar Programs, Washington, Forrás: https://www.wmata.com/about/board/meetings/boardpdfs/upload/030206_SemiAnnualRptonRailcarPrograms030206.pdf, Letöltve: 2020.04.23. 09:00 